\title{
Culture Acculturation between Batak Ethnic and Chinese Ethnic
}

\author{
Yasnita Yasinta*, Raharjo Raharjo, Nadiroh Nadiroh \\ Pancasila and Civic Education Program Study \\ State University of Jakarta \\ Jakarta, Indonesia \\ *yasnita816@gmail.com
}

\begin{abstract}
This study discuss how culture acculturation take place between Batak ethnic and Chinese ethnic. Teachers who come from Batak ethnic in this school become the newcomer and Chinese ethnic as the host. This study about intercultural adaptation refer to model system which is elaborated by Ruben, namely interrelatedness between personal communication and social communication comprising interpersonal communication and mass communication which is not separated from communication environment to measure communication competence among teachers who come from Batak ethnic in Chinese ethnic environment. The approach used in this study is qualitative approach with flow model of analysis. The study result showed that Batak ethnic is well-known by their harsh character and not easily influenced but in fact they can adapt and experience acculturation which is supported by the potential of acculturation of Batak ethnic toward Chinese ethnic, among others are the similarity in culture values and in religion, and the most important thing is the support from school environment which is very conducive and support intercultural adaptation, because anyway acculturation cannot take place without acceptance from the host environment. Another more interesting thing is that they had absorbed the values of Batak ethnic but strive to maintain their own cultural identity. Finally, this study show how school can become acculturation space to shape intercultural personality.
\end{abstract}

\section{Keywords-acculturation; batak ethnic; chinese ethnic}

\section{INTRODUCTION}

Indonesia is one largest multicultural country in the world consisting of various background in religion, tribe, language, color of skin, custom, etc. This diversity give rise the unique identity among each ethnic. It means that each ethnic has its own cultural identity which is differ among each other. According to Ting-Toomey, cultural identity is one's feeling (emotional significance) and has sense of belonging or affiliated with certain culture [1].

This diversity converges in a space named Indonesia. Through intensive communication, the ethnics become acculturated among each other's. This article will discuss acculturation between Batak ethnic and Chinese ethnic as two ethnic group which have the high number of population in Indonesia. According to population census in 2010, Batak ethnic is in the $3^{\text {rd }}$ rank after Java and Sunda, with population achieve 8.47 million people (3.58\% of total population of national population) whereas Chinese ethnic (Tionghoa) is the $18^{\text {th }}$ rank with population achieve 2.83 million people $(1.2 \%$ of total population of national population) [2].
Revida in a study titled social interaction between Chinese ethnic and native people in Medan City, North Sumatera shows that social interaction between Chinese ethnic and Indonesian native people in Medan often face threat or problem. There is negative stereotype toward each other. This stereotype had been developed since colonial period and it still become a problem until now. This stereotype is actually latent danger inculcated in relation between Chinese ethnic and Indonesian native people [3]. Another study on relation between Batak ethnic and Chinese ethnic was conducted by Lubis who explain that intercultural communication can change the view of cultural values of Tionghoa and native people in Medan City which drive individual behavior to become more positive [4].

By referring to it, it is interesting to track deeply culture acculturation between Batak ethnic and Chinese ethnic in the environment of Chinese ethnic majority. Its meaning become significant in the context that Indonesia is one largest multicultural country in the world. The study on interethnic acculturation including acculturation potential is scarce, whereas in the life of Indonesian people, living together with another ethnic is a necessity. Thus, knowing how culture acculturation between Batak ethnic and Chinese ethnic will give new views, that each ethnic can absorb positive values from another ethnic if they are open each other. This study uses qualitative method and its result showed that acculturation had taken place that Batak ethnic and Chinese ethnic aware [4].

\section{CONCEPTUAL FRAMEWORK}

\section{A. Culture Acculturation}

Conceptually, intercultural adaption and acculturation is understood as a concept containing learning process and selfadjustment with new culture behavior which is differ with origin culture. Jamaludin Rahmat and Dedy Mulanya mention it as a process done by immigrant to self-adjust with and to acquire the native people culture, which finally lead to assimilation. Assimilation is the highest degree of acculturation which theoretically can take place and for most immigrants, assimilation is the goal of long life [5].

Zamboaga et al explain that culture acculturation is not related to perception but awareness. That awareness can be build by continuously increase students' knowledge and understanding about diverse cultures and it can be done through role- play. Therefore, whatever method used in class, it only facilitates students to find their own awareness as the door to make acculturation take place [6]. 
That awareness is very important to remove interethnic prejudice, particularly in multicultural life like in Indonesia. Brown et al studied ethnic prejudice among children in Indonesia. This study used a method of reading the story about friendship between two children who come from two different ethnics (Chinese ethnic- high status) and Papua ethnic (low status). Subject in this study are children in Jakarta and Bandung. The result showed that children who often told the inclusive stories tend to be tolerant to another ethnic. It is different with children who are rarely told or informed about the inclusive things [7].

\section{B. The Process of Acculturation and the Variables of Communicatio in Acculturation}

Acculturation is a process which interactively "push and pull" between an immigrant and native people environment, which take place in communication event. Young Yun Kim in his idea about communication and acculturation in Samovar and Porter state that one conceptual framework which is most comprehensive and beneficial in analyzing acculturation of immigrant contained in System Perspective elaborated by Ruben [8-10]. In system perspective, the basic element of a communication system in human is observed when people is actively communicating, try and expect to communicate with environment.

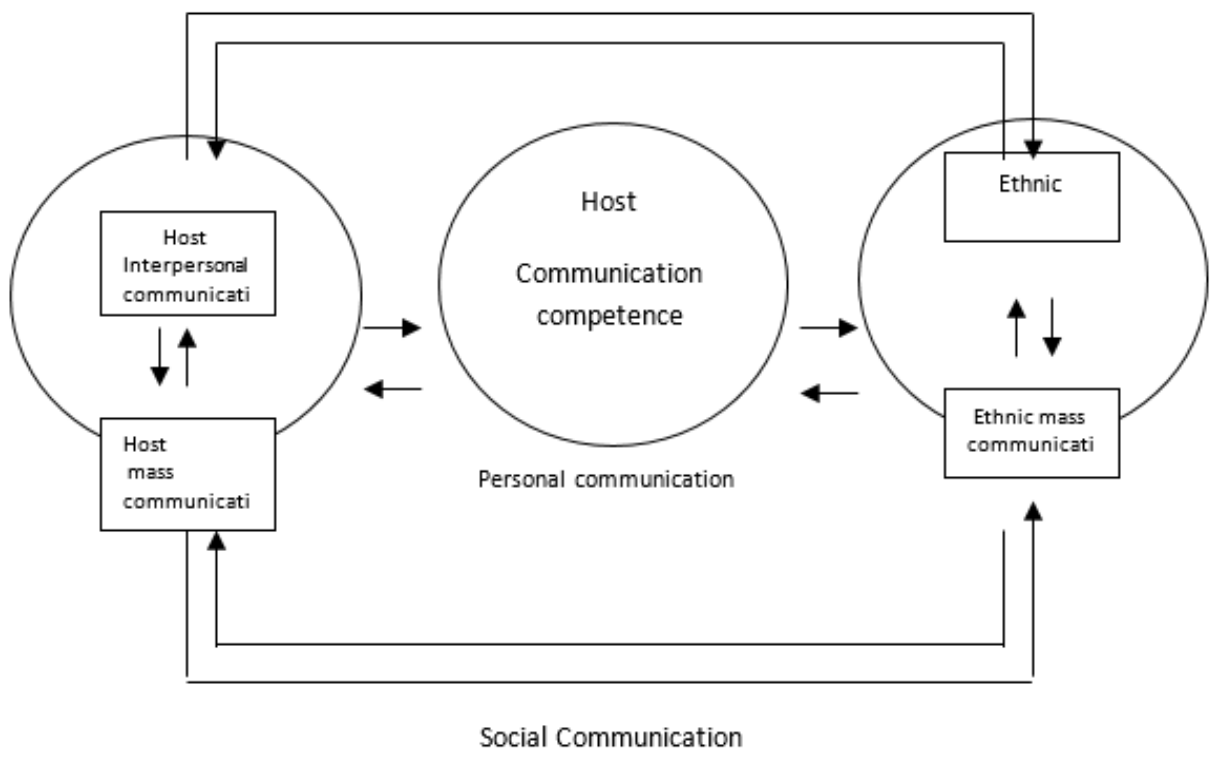

Fig. 1. Interrelated process of personal and social communication [8].

\section{The Potential of Acculturation}

Despite as a process, according to Kim, the patterns of acculturation is not uniform among individual but it is varied depend on the potential of acculturation owned. The factors which are considered as important and become the potential of acculturation is: (1) The similarity between original culture and indigenous culture; (2) the age when they migrate; (3) Education background; (4) Personality factor; (5) Immigrant' knowledge acquired before about indigenous culture before they migrate; (6) the degree of balance or difference; (7) the degree of difference in physical appearance; (8) environment [8].

\section{METHOD}

The approach used in this study is qualitative, with focus of study is on process and not in outcome. According to Bryman in Dedy, the observation unit in this study are teachers who come from Batak ethnic in Chinese ethnic environment, whereas the analysis unit is group namely Batak ethnic. The informant in this study are 3 (three) teachers who come from Batak Toba and Batak Karo, 4 (four) students of SMPK Penabur, and an expert in Batak Culture [5].
The analysis model used is flow model of analysis. The researcher moves among three components: data collection, data processing, and conclusion drawing as cyclic process [11]. This study was conducted in SMPK 4 Penabur Jakarta. Data collection was done through 3 (three) methods, namely: direct observation, in depth interview and literature study. To maintain the validity of this study, researcher had discussed this study result with Mrs. Jenny Syika Sinaga who is an expert in Batak Culture.

\section{STUdy RESUlT AND DisCUSSION}

\section{A. Intercultural Adaptation Done by Batak Ethnic Teachers in Chinese Ethnic Environment}

Culture acculturation occur in SMPK 4 BPK Penabur Jakarta is implication of intercultural adaptation done by teachers who come from Batak ethnic in Chinese ethnic environment, which take place through communication process. The study result can be seen from the Table I below. 
TABLE I. CULTURE ADAPTATION

\begin{tabular}{|c|c|c|c|c|c|}
\hline Inf & $\begin{array}{c}\text { Host } \\
\text { Interpersonal } \\
\text { Communication }\end{array}$ & $\begin{array}{c}\text { Host } \\
\text { Mass Communication }\end{array}$ & $\begin{array}{l}\text { Ethnic Interpersonal } \\
\text { Communication }\end{array}$ & $\begin{array}{l}\text { Ethnic Mass } \\
\text { Communication }\end{array}$ & $\begin{array}{c}\text { Host } \\
\text { Competence } \\
\text { Communication } \\
\end{array}$ \\
\hline 1 & $\begin{array}{l}\text { Communicate actively } \\
\text { with students or } \\
\text { students' parent, both in } \\
\text { learning activity and } \\
\text { beyond learning activity. } \\
\text { Treat students like their } \\
\text { own children so more } \\
\text { empathize to them. }\end{array}$ & & $\begin{array}{l}\text { The religious worship } \\
\text { place in HKPB which is } \\
\text { intended to Batak Toba } \\
\text { Christians. } \\
\text { Follow praising activity, } \\
\text { door to door worship to } \\
\text { Chinese ethnic houses } \\
\text { existed in residential } \\
\text { environment and } \\
\text { occasionally do worship } \\
\text { in Bethel Church, } \\
\text { Indonesia which more } \\
\text { mingle with Chinese } \\
\text { ethnic. }\end{array}$ & $\begin{array}{l}\text { Seldom following the } \\
\text { Batak custom ritual. }\end{array}$ & $\begin{array}{l}\begin{array}{l}\text { Feeling united } \\
\text { Chinese } \\
\text { environment. }\end{array} \\
\begin{array}{r}\text { with } \\
\text { ethnic }\end{array} \\
\begin{array}{l}\text { Can self adjust and } \\
\text { experience } \\
\text { absorption } \\
\text { inculcating } \\
\text { student. }\end{array}\end{array}$ \\
\hline 2 & $\begin{array}{l}\text { Communicate well with } \\
\text { students and students' } \\
\text { parents. }\end{array}$ & & Do worship in HKBP & $\begin{array}{l}\text { Occasionally follow } \\
\text { Batak people ritual and } \\
\text { obey Batak philosophy } \\
\text { "Menjunjung } \\
\text { Baringina". }\end{array}$ & $\begin{array}{lr}\text { Can self } & \text { adjust and } \\
\text { experience } & \text { values } \\
\text { absorption } & \end{array}$ \\
\hline 3 & $\begin{array}{l}\text { Communicate actively } \\
\text { with students and } \\
\text { involve parents in } \\
\text { students affairs. They } \\
\text { just wait the instruction } \\
\text { from the school leader. } \\
\text { if there is assignment } \\
\text { they are ready to do it. }\end{array}$ & & $\begin{array}{l}\text { The worship place in } \\
\text { GBKP (Gereja Batak } \\
\text { Karo Protestan) }\end{array}$ & $\begin{array}{l}\text { Actively attending Batak } \\
\text { custom ceremonies. }\end{array}$ & $\begin{array}{l}\text { Capable to self adjust but } \\
\text { will study the host } \\
\text { community until they } \\
\text { can accept differences. } \\
\text { Absorb the values as } \\
\text { well as transfer the } \\
\text { values to student. }\end{array}$ \\
\hline
\end{tabular}

In general, the informant's posse's communication ability which is quite good, not only with students, but also with students' parent and school leaders.

\section{B. The Potential of Culture Acculturation among Batak Ethnic Teachers and Chinese Ethnic Environment in SMPK 4 BPK Penabur Jakarta}

The following is the potential things which enable culture acculturation experienced by teacher who come from Batak ethnic in Chinese ethnic environment after study was conducted on intercultural adaptation done by Batak ethnic teachers.

\section{Similarity among Batak Culture and Chinese Culture}

According to Kim, the similarity between original culture of immigrant and native people's culture probably is the most important factor which support acculturation potential. It seems that Kim assumption can be proved in this study. Regarding similarity, it is clearly revealed by informant [8].

"We have some common in values, namely reactive and open. In general, Batak people are reactive and open, and in fact Chinese people own those values also. In that stage, as if that we have a common, so it is easier to make adaptation even though we are different."

The informant admits that between Batak ethnic and Chinese ethnic have a common in some values. This similarity not only mentioned by teacher informant as well as student informant,

"Certainly, we will accept what is good, for example, Batak people speak openly, just the way they are. We like this, so there is nothing to be kept. But we still have our own culture, not disturb each other."

\section{Age when immigrating}

Refer to Kim opinion about the age factor as one potential of acculturation, it seems that the informants are totally disagree, because the important thing is maturity and attitude. According to informant, age is the number which cannot measure the quality of one's maturity, even in facing the life which is very different with personal life.

\section{E. Educational Background}

The informants are strongly agree that the educational level is considered as potential of intercultural adaptation, even though it doesn't mean that people with high level of education must have mature personality, but at least it much influence it. It is because educational level become indication of how much learning experience acquired, particularly in formal education.

"Certainly, level education is influential.....Education according to me will influence how we talk, show attitude and understand ethic.... even though not all people who have high education also display such attitude, because the most important is attitude."

Equipped by this education, the informants are easier to do intercultural adaptation which is finally acculturated with Chinese ethnic, an environment where they teach now.

\section{F. Friendly and Tolerance Personality}

Kim is not wrong in mentioning that personality factor is one potential of culture acculturation. Let's see the informant's opinion about this. 
"Yes .... personality influence self-control.... person who has mature personality has more extra self control. Now I am 45 years old.... I treat them as my own children.... because they also treat me like a mother for them, not merely as teacher. So, there is reciprocal relation. A person who has mature personality usually more ready to face new situation. She/he can regulate and measure children needs suited with their age level, of course it is always connected to learning material. Children in general prefer friendly teachers, who can befriend with them.... but again, it doesn't mean that person with mature age and high level of education also has mature personality. Thus, personality also very support adaptation, because we are more ready to accept the difference."

This informant fulfills that qualification standard in which she is very friendly and pleasant.

\section{G. Knowledge about Chinese Ethnic Before Immigrating}

According to informant, initial knowledge is very needed, moreover when entering new environment, such the statement below.

"Yes, in first interview I said that initially I know that Chinese people has high egoism, spoilt, and feeling superior. I get that information from various sources like I hear people say that. But I also know them from worship activity. Accidently most of them are Charismatic Christian. They do worship in Bethel church, and accidently there also Batak people there, perhaps until $50 \%$. So, we frequently meet before, whether it is in Church Service and another activity. From those meetings I had knew them. According to me, I have initial knowledge that the environment we will enter is very important, otherwise we will know nothing, finally it will make us nervous. If we have knowledge about them, we will know what we should do to dealt with them."

Initial knowledge about Chinese ethnic possessed by Batak ethnic teachers is very important to increase their participation in interpersonal communication and mass communication network which exist in native people (Chinese ethnic) [5, 8].

\section{$H$. The degree of balance and difference between Batak ethnic and Chinese ethnic}

One factor which support culture acculturation is degree of balance and difference between two ethnic or more which are joined in culture contact. As revealed by an informant:

"Another thing which unite us, in addition we have some similarities in cultural values is.... because we are all under the church.... because our same faith...."

The common in faith seems to be red thread which give big effect to one's ability to be acculturated, particularly in dominant culture environment. Because of this common, informant feel they are balanced, equal, because they have the same faith.

Regarding the difference in socioeconomic status, the only way according to Jersild in Semiawan is by "entering their world with the story suited with their world," so there is emotion encounter and involvement, understanding and mental involvement between storyteller and the child. Thus, two side experiences are realized between the storyteller and listener [12].

\section{Degree of difference in physical appearance}

Regarding the degree of physical difference, the informant explains,

"Actually we are very different physically..... but because we often meet, at least when we do worship in Church (Bethel) whose congregators are Batak and Chinese people, then we will be accustomed with this difference......therefore, physically there is no problem even though we are different...."

Thus, this difference can be bridged with encounter beyond study hours, when do worship in church.

\section{J. Environment where the adaptation occur}

SMPK 4 BPK Penabur Kepala Gading Jakarta is friendly school. It is based on researcher experience when visiting this school several times. As illustration, when researcher meet some students, they spontaneously say good morning, good afternoon or good evening. The environment where the informants are adapted is sufficient to give opportunity to them to be able to do intercultural adaptation maximally, as the following statement:

"Yes....according to me, this school is quite open for everyone.....the system build is quite democratic. We have forum called Communication Seminar which always be done regularly by each level existed in this institution, started from Kinder Garden, Elementary School, Junior High School and Senior High School. In that activity, we are accustomed to share our problems we experience.... even though our leader is native Chinese, but the system build not make us feeling different, even though we are newcomer......moreover, the teachers in school are quite diverse both in ethnic and religion...."

\section{K. Culture Acculturation experienced by Batak ethnic teachers in Chinese ethnic environment in SMPK 4 BPK Penabur Jakarta}

Earlier, it had been explained that culture acculturation discussed in this study is acculturation in individual not in group as referred from the thinking of T.D. Graves [13]. Even though in-depth study is focused on individual acculturation, but the origin ethnic cannot be detached as a system. Related to it, it is interesting to consider what had been explained by the informant about the natures related to Batak people values.

"According to me there are five things which should be noted from Batak people. First, regarding family relation. Batak people have strong and tight family relation, even though there are not belong to one kinship. Moreover, if they are belonging to one marga, then this relation will become tighter. For example, I am Siaga, then someone who has also Siaga marga is sick, then we will immediately help him/her. Second, Batak people have harsh character. Batak people generally like food derived from animal, and it influence their blood pressure which is automatically make their high temperament reflected in their loud voice. Batak people also have rude and loud dialect. Third, Batak people is well-known with their character namely brave, hardworking and persevere. 
I think this courage also strongly related to the environmental condition in their origin region. Forth, Batak people generally have loyalty/dedication, particularly toward responsibility. Fifth, mutual cooperation. If there are another Bataks who is sick, moreover from one marga, then we will immediately help $\operatorname{him} /$ her."

This explanation from informant is in accordance with Narrol definition as well as with what had been found by Schweizer who had successfully identified the characteristics of Batak ethnic, namely preserve, diligent, developed, harsh, brave and energetic [5].

Acculturation is a process which do not occur as simple as though. Teachers who come from Batak ethnic in SMPK BPK Penabur are confronted with Chinese culture which is differ with their culture. Even though gradually as the time passed, there are some values of Chinese culture which are accepted and processed into Batak culture element, but they do not omit the character of Batak culture, or Batak cultural values believed so far.

"I feel that I am not changed as a Batak. I keep hold firmly Batak values which become our culture so far. I think it has relation to one Batak philosophy, "Manjunjung Baringina", which means upholding family values. Thus, wherever we stay, we still Batak people who always bring family values."

As confirmative data, the researcher also interview an informant, a Public Figure of Batak Society who live in Bekasi. She also explain the same thing, that make self adjustment with another culture needs process. Even though she has stay for a long time in environment whose inhabitants are people with different culture, but that informant does not loose his identity as Batak people.

"Self adjustment need process, I have been 29 years live here (Bekasi- red). The neighbors around here generally are Javanese. I think for 29 years we try to understand their tendencies, their communication pattern and how they interact with another people. I also often follow the activities done by my neighbors such as gathering, etc. Similarly, with what I do in factory (Informant is one of managers in a Garment Factory). Nevertheless, I confirm again that We are still Batak people. Naturally, there are values from another culture that I learn, such as more patient and polite.... of course this influence me because I had mingled for a long time with people from different culture."

It is not surprise to see Batakness identity which so attached in them, because Batak people have a life philosophy, as stated by an informant,

Batak people have a life philosophy, namely......" Marsipature Hutanabe"

Which perhaps means "wherever you live, you should maintain your culture image and prioritize to build your region" ......So, wherever we live and with whoever we mingle we are still Batak people.
This philosophy is held firmly by Batak people and internalized in their life. Whatever marga they own, they are still Batak people who always hold Batak people values.

\section{CONCLUSION}

Batak ethnic and Chinese Ethnic are two big ethnics in Indonesia. These two ethnics have culture uniqueness and identity which is different between each other. Culture acculturation between Batak ethnic and Chinese ethnic occur because these two ethnics have potential to be acculturated. These potentials among others are similarity in culture, age maturity, education background, personality, degree of difference and similarity, and knowledge. Therefore, acculturation only take place when it is supported by those potentials.

\section{ACKNOWLEDGEMENT}

The author would like to say thank to all informants and key informant who had gave enrichment and information to the author

\section{REFERENCES}

[1] S. Ting-Toomey, Comunicating Across Cultures. New York: The Guilford Publications, Inc. 1999

[2] Databok katadata.co.id, 1,2 "Persen Penduduk Indonesia Adalah Etnis Cina", Retrieved from: https://databoks.katadata.co.id/datapublish/2017/01/28 Accesed, 21 August 2018.

[3] E. Revida, Interaksi Sosial Masyarakat Etnik Cina dengan Pribumi di Kota Medan Sumatera Utara, Interaksi Sosial Masyarakat Etnik Cina Dengan Pribumi Di Kota Medan Sumatera Utara, 2006.

[4] L. Andriani, "Komunikasi antarbudaya etnis tionghoa dan pribumi di kota medan,” Jurnal Ilmu Komunikasi Terakreditasi, vol. 10, no. 1, pp. 13-27, 2012.

[5] D. Mulyana and J. Rahmat, Komunikasi Antarbudaya, Bandung: PT. Remaja Rosdakarya, 2006

[6] B.L. Zamboanga, L.S. Ham, C.C. Tomaso, S. Audley, and N. Pole, ""Try Walking in Our Shoes": Theaching Acculturation and Related Cultural Adjustment Processes Through Role-Play," teaching of Psychology, pp. 1-7, 2016.

[7] C.S. Brown, M. Tam, and F. Aboud, "Ethnic Prejudice in Young Children in Indonesia:Intervention Attempts Using Multicultural Friendship," IJEC, 1-18, 2018.

[8] W.B. Gudykunst and Y.Y. Kim, Communication with Strangers, an Approach to Intercultural Communication $3^{\text {rd }}$ Ed. New York: McGrawHill, 1997.

[9] L.A. Samovar and E.P. Richard, Intercultural Communication: A Reader. USA: Wodswort, 1988.

[10] B.D. Ruben, "Human communication and cross-cultura effectiveness," International and Intercultural Communication Annual, vol. 4, pp. 95-105, 1977.

[11] H.B. Sutopo, Pengantar Penelitian Kualitatif (Dasar-Dasar Teknis dan Praktis) Surakarta: UNS Press, 1998

[12] C.R. Semiawan, Landasan Pembelajaran dalam Perkembangan Manusia, Jakarta: Centre of Human Competency Development, 2007.

[13] T.D. Graves, "Psychological acculturation in a tri-ethnic community," Southwestern journal of anthropology, vol. 23, no. 4, pp. 337-350, 1967. 